\title{
Review
}

\section{Synthetic Musk Fragrances in Water Systems and Their Impact on Microbial Communities}

\author{
Vitória Arruda ${ }^{1,2,+}$, Manuel Simões ${ }^{1,2, *}$ a and Inês B. Gomes ${ }^{1,2,+}$ \\ 1 LEPABE, Department of Chemical Engineering, Faculty of Engineering, University of Porto, \\ 4200-465 Porto, Portugal; up201606060@edu.fe.up.pt (V.A.); ibgomes@fe.up.pt (I.B.G.) \\ 2 ALiCE-Associate Laboratory in Chemical Engineering, Faculty of Engineering, University of Porto, \\ 4200-465 Porto, Portugal \\ * Correspondence: mvs@fe.up.pt \\ + These authors contributed equally to this work.
}

Citation: Arruda, V.; Simões, M.; Gomes, I.B. Synthetic Musk Fragrances in Water Systems and Their Impact on Microbial Communities. Water 2022, 14, 692 https://doi.org/10.3390/w14050692

Academic Editors: Monica Rivas Casado, Paul Leinster and Guangtao Fu

Received: 2 February 2022 Accepted: 20 February 2022 Published: 22 February 2022

Publisher's Note: MDPI stays neutral with regard to jurisdictional claims in published maps and institutional affiliations.

Copyright: (C) 2022 by the authors. Licensee MDPI, Basel, Switzerland. This article is an open access article distributed under the terms and conditions of the Creative Commons Attribution (CC BY) license (https:// creativecommons.org/licenses/by/ $4.0 /)$.

\begin{abstract}
The presence of emerging contaminants in aquatic systems and their potential effects on ecosystems have sparked the interest of the scientific community with a consequent increase in their report. Moreover, the presence of emerging contaminants in the environment should be assessed through the "One-Health" approach since all the living organisms are exposed to those contaminants at some point and several works already reported their impact on ecological interactions. There are a wide variety of concerning emerging contaminants in water sources, such as pharmaceuticals, personal care products, house-care products, nanomaterials, fire-retardants, and all the vast number of different compounds of indispensable use in routine tasks. Synthetic musks are examples of fragrances used in the formulation of personal and/or house-care products, which may potentially cause significant ecotoxicological concerns. However, there is little-to-no information regarding the effect of synthetic musks on microbial communities. This study reviews the presence of musk fragrances in drinking water and their impact on aquatic microbial communities, with a focus on the role of biofilms in aquatic systems. Moreover, this review highlights the research needed for a better understating of the impact of non-pharmaceutical contaminants in microbial populations and public health.
\end{abstract}

Keywords: aquatic biofilms; drinking water; galaxolide; synthetic musks; tonalid

\section{Introduction}

Emerging contaminants (ECs) or micropollutants are increasingly becoming a worldwide concern. These contaminants correspond to a wide range of natural and anthropogenic substances, indispensable to current societal demands, that are consistently found in the environment (i.e., groundwater, surface water, watercourses, wastewater, soil, drinking water (DW), and food sources) [1]. The term "emerging" encompasses novel synthetic, natural, or biological compounds or pre-existing compounds which are of increasing concern [2].

A compound is characterized as an EC according to the three following features: (1) persistence - their chemical stability and persistence in the environment; (2) lipophilicity - their ability to accumulate in fat tissues and, subsequently, their biomagnification and bioaccumulation potential; and (3) acute or chronic toxicity [2]. However, this approach proves to be too generic and inadequate to classify some contaminants, particularly due to the existence of pseudo-persistence; active transportation of some drugs into cells (regardless of their lipophilicity); and due to the existence of chemical compounds that act as indirect toxicants [2].

Among a wide variety of ECs, they can be categorized into different classes, such as surfactants, plasticizers, flame retardants, biological ECs, nanomaterials, and pharmaceuticals and personal care products (PPCPs) [3]. PPCPs comprise several chemicals used in health products (prescription medication, over-the-counter medication, and supplements) or for cosmetic purposes, namely fragrances, UV filters, antimicrobial preservatives, and 
insect repellents [3]. The main problem regarding PPCPs is not owed to their structural stability, but to their repeated disposal, which ultimately leads to their environmental persistence [4]. The external use of personal care products (PCPs), such as lotions, cosmetics, and fragrances, drives these compounds and their metabolites into sewage and consequently into wastewater treatment plants (WWTPs), which are often not prepared to remove them completely [5]. There is limited research regarding the harmful effects of the exposure to certain ECs on human beings (mostly due to ethical reasons). Exposure to some chemicals could be linked to some diseases such as specific forms of cancer, cognitive disorders in children, asthma, amyotrophic lateral sclerosis (ALS), and infertility [2]. Besides that, there is little information regarding the toxicological relevance of ECs in ecosystems, particularly when it comes to chronic toxicity associated with long-term exposure to low concentrations, which is fairly pertinent since humans and wildlife alike are constantly exposed to ECs, typically at low levels [2]. For instance, Smital [2] offers an ecotoxicological perspective on the problem of ECs, with an overview of acute and chronic toxic effects on humans and wildlife. Furthermore, recent studies have demonstrated the impact of the presence of ECs in different environments, highlighting their potential health risk for various species as well as their harmful effects on an environmental level [6-12]. The presence of ECs in different aquatic ecosystems can produce antagonistic effects on their animal populations. For example, Brodin, et al. [13] assessed the behavior of a type of perch (Perca fluviatilis) and its prey (Coenagrion hastulatum) after exposure to oxazepam, an anxiolytic drug. The authors found that the drug affected both species differently, which could lead to disruptions in interactions between species, specifically, interactions between predator and prey. However, besides animal exposure to ECs, the interaction of those contaminants with microbial communities in the environment should not be disregarded.

Most of the studies found in the literature focus on the impact of ECs in aquatic microbial communities (rivers, lakes, marine sediments, and in WWTPs). In fact, bacteria enclosed in aquatic biofilms can interact with ECs in the form of colloidal and dissolved organic and inorganic materials, where adsorption and/or dissolution processes may take place [14]. The contaminants in water come into contact with the microorganism surface, where interactions with membrane binding sites may lead to adsorption and, subsequently, uptake of these compounds [15]. Microorganisms in biofilms can also produce vesicles and compounds that enable the uptake of contaminants, such as siderophores and citrates, by complexing or solubilizing ECs [15]. In addition, several contaminants can interact with the extracellular polymeric substances (EPS) of biofilms through retention in the EPS matrix or by chemical interactions with EPS functional groups [16]. However, the literature has a gap in the understanding of the impact of non-pharmaceutical ECs, more specifically, non-antibiotic ECs, on microbial communities. This literature review is focused on the impact of microbial exposure to musk fragrances. Musk fragrances have been widely used in a varied range of products from soaps, shampoos, and perfumes to detergents and household products. Since they are often detected in the environment, specifically in water sources, and due to their impacts on aquatic ecosystems, musk fragrances have been considered ECs. However, information regarding their impact on microbial communities, and more specifically in these from DW systems, is scarce. Therefore, this work aims to highlight the impact of musks in aquatic systems as well as to point out the need to better understand the impact of non-pharmaceutical contaminants in microbial populations and, consequently, their possible impact on public health. The role of biofilms in aquatic systems is critically assessed, taking into account that microorganisms are typically found in nature as living in biofilms.

\section{Biofilms in Aquatic Systems}

Biofilms can be found on almost every aqueous system able to support life, or any interface, as long as they are exposed to water for long enough [17]. These are encountered in diverse aquatic ecosystems, not only in marine environments, which include the pelagic, limnetic, neritic, and oceanic marine regions, but also in wetlands and freshwater 
environments, such as rivers, lakes, and streams [14]. In these habitats, biofilms can be formed in streambed cobbles and rocks, sand, sediment, wood, and leaves, on the surface of submerged plants and as macro- or micro-aggregates [14,18]. Moreover, biofilms may also be found in man-made structures, such as WWTPs, drinking water distribution systems (DWDSs), or plumbing systems.

Aquatic biofilms are generally composed of diverse microorganisms, being largely dominated by bacteria, including $\alpha, \beta$, and $\gamma$-proteobacteria, Bacteroidetes, and cyanobacteria, but also algae, metazoans, and fungi $[14,19]$. The organisms are encased in a selfproduced matrix composed of EPS and detritus and are usually found in aquatic environments $[17,18]$. However, the composition of biofilms varies according to the environment in which they are inserted. For instance, biofilms formed in freshwater environments, specifically in a benthic substrate, are rich in photoautotrophic algae, heterotrophic and chemoautotrophic bacteria, fungi, protozoans, metazoans, and viruses, and these are usually referred to as periphyton [20]. On the other hand, biofilms existent in marine environments are characterized by a community of photoautotrophic microorganisms, such as algae (i.e., diatoms, euglenids, crysophyceans, and dinoflagelates) and cyanobacteria, and these are referred to in the literature as microphytobenthos [21,22]. Another particular example of biofilms are the "microbial mats", which consist of sedimentary biofilms attached to solid surfaces organized in a layered structure, resulting from sediment binding in combination with carbonate precipitation, as a consequence of microbial activities [18]. Microbial mats are found in several aquatic ecosystems, from lagoons, rivers, and lakes to some unconventional environments, such as hypersaline ponds and hot springs, and are usually formed by sulfuric bacteria, cyanobacteria, and sulfate reducing bacteria [23].

The presence of biofilms in aquatic habitats is vital for the proper functioning of ecosystems. Biofilms, particularly those in the form of aggregates or granules, are actively engaged in the accumulation and degradation of organic and inorganic matter, nutrient dynamics, and biogeochemical cycles [14,24,25], participating as well in photosynthetic processes [26] and being a part of food webs [27]. So, biofilms play a crucial role in water purification, being able to degrade pollutants and represent generally a viable process to improve the quality of water [25]. Nevertheless, biofilms present in different environments and with different compositions will play different roles in biological degradation. For instance, in freshwater environments, biofilms attached to sediments play a more significant role in the decomposition of organic matter when compared to biofilms developed on rocks, since heterotrophic bacteria and fungi are more prevalent on the first ones [18,24,28]. Moreover, aquatic biofilms also act as good indicators of water quality and overall ecosystem health [29].

The survival of aquatic biofilms, both in man-made surfaces and in natural aquatic environments, is dependent on a series of factors. In general, biofilm development in aquatic ecosystems is mostly dependent on environmental variables, such as the characteristics of the surrounding water (i.e., temperature, $\mathrm{pH}$, and nutrient levels). However, specific environments may exhibit other relevant factors [18]. For instance, man-made surfaces carry many specific factors which influence biofilm development, such as water flow velocity, surface material characteristics and the concentration of disinfectants, besides the water composition and its characteristics [30]. Wimpenny, Manz, and Szewzyk [17] in their extensive review highlighted the most important general factors for biofilm development. Biofilms, in man-made systems and aquatic environments, confer advantages to colonizing microorganisms. These advantages are mostly translated in protection against protozoan grazing, multiple environmental stress factors, and against host defenses, in the case of biofilms associated with plants and animals [31,32]. Furthermore, biofilms in aquatic ecosystems are met with a nutritionally rich environment, since the adhesion of these microorganisms to surfaces allows them to contact with an interface abundant in organic and inorganic nutrients, and a filtration process allows the retention of these same nutrients [33]. 
Drinking water treatment plants (DWTPs) and WWTPs have taken advantage of biofilms as water purificators, successfully implementing these in some processes, e.g., for the removal of nutrients such as nitrogen and phosphorus [34], activated sludge treatments, fixed-film reactors, and up-flow anaerobic sludge blanket (UASB) reactors [17]. In contrast, biofilms also prove to be detrimental in this same context, causing significant issues in several man-made systems, such as DWTPs, WWTPs, DWDSs, and plumbing systems. One of the major problems associated with biofilms in these settings is biofouling, which is described as the process by which organic and inorganic particles, as well as microorganisms, accumulate on surfaces in contact with an aqueous phase [35]. Biofouling is a problem especially notorious in marine systems, such as aquaculture nets, oil and gas installations, and ship hulls [18]. Marine biofilms are one of the major contributors for marine biofouling, promoting the adhesion of other organisms, such as barnacles on ship hulls [36], which in turn leads to increased frictional drag and high costs associated with fuel consumption [37]. The occurrence of biofouling in DWTPs and WWTPs is also responsible for considerable challenges, namely corrosion of metal pipes and equipment, and product contamination [38].

\subsection{Biofilms in Drinking Water}

The occurrence of microorganisms in DWDS is quite common. Approximately $95 \%$ of these microorganisms grow associated with biofilms present in, ultimately, all interfaces, from pipe walls through the distribution system, to house installations, on sediments and suspended particles [17,39]. Adsorption of organic and inorganic particles occurs when water is in contact with pipes [40], forming a conditioning film. This phenomenon is followed by the adhesion of microorganisms [40], which consume the nutrients in the conditioning layer as well as the ones existent in the flowing water through a process of diffusion, allowing biofilm growth and maturation [40]. The microbial cells present in the DWDSs are dependent on the nutrients available in the water, and if the nutrient demand is not met, these cells are not able to multiply and are ultimately washed out of the system [40]. Considering the low nutrient content in DW, it is thought that the formation of biofilms in these systems occurs as a response to such and, ultimately, as a survival mechanism [40].

Biofilms in DW appear as complex systems, typically harboring environmental bacteria (i.e., Pseudomonas and Flavobacterium species), in addition to pathogenic or potentially pathogenic bacteria, filamentous bacteria and fungi, viruses, freshwater diatoms and corrosion products [39-41]. Similarly to other types of biofilms, the formation and subsequent development of DW biofilms are also affected by a series of physical and chemical factors. The most noteworthy conditions that impact biofilm development and characteristics are the water temperature, the amount of utilizable carbon, the disinfection treatment applied, the presence of corrosion products, and the hydrodynamic conditions of the system [42]. Given these factors, it is not surprising that biofilms in DWDSs are often presented as heterogeneous, both from qualitative and quantitative perspectives [40]. So, biofilms in different conditions also appear to display different structures. One of the most significant findings on the structure of DW biofilms lies in the fact that when developed in the presence of a chlorine disinfectant are different from these developed in the absence of disinfectant, with the chlorinated biofilms appearing patchier and the cells remaining aggregated only in clumps [42]. Moreover, the cells in the chlorinated biofilms are 50\% smaller while the cell density remains roughly the same. More recently, Fish et al. (2017) studied the effects of hydrodynamic conditions on biofilm structure and found that higher flow variations formed biofilms with higher biomass amounts, while biofilms developed under low-varied flow conditions had the largest volumes of EPS per cell [43].

Biofilms adhered onto pipe walls in DWDSs are associated with a myriad of problems. These represent one of the largest contributors to the deterioration of DW, essentially through the detachment of biofilm cells and subsequent contamination of the water phase [39]. Despite continuous disinfection strategies, the formation of biofilms in DWDSs is inevitable [44]. These biofilms can harbor pathogens, which remain present through the 
path of the tubing systems, up until the consumers' tap, where the detachment of biofilm portions and ensuing expulsion may harm the health of consumers and cause disease outbreaks in populations [45]. Microorganisms in DW may be originated from the water source, treatment steps or water distribution network, essentially due to detachment and dispersion of the biofilm [46]. Considering the issues surrounding biofilms in DWDSs and their inevitability in these systems, control strategies are of utmost relevance. Disinfection processes are continuously applied in DWDSs as a method to remove pathogens and prevent public health hazards. Thus, the applied disinfectant should be able to adapt to varying microbial compositions in the water and provide protection against recolonization, all while not being toxic and not producing toxic by-products [47]. Nevertheless, classical disinfectants are somehow inefficient at removing attached biomass since biofilm removal requires higher concentrations than the ones applied to planktonic bacteria [47]. To control the formation of biofilms, the use of a combination of mechanical and chemical processes is advised for higher biofilm removal efficiencies, paired with regular cleaning as a form of prevention [40]. The excessive use of biocides could also become detrimental due to the development of tolerance [47]. In this way, microbial growth in DW poses not only a concern regarding consumer safety but also represents a relevant challenge for the overall process of water distribution [46]. Biofilms in DWDSs are also intimately linked to corrosion of the pipelines. The formation of thick mature biofilms leads to a depletion in oxygen levels, creating an anaerobic environment in the layers below the surface. Anaerobic conditions promote the growth of sulfate reducing bacteria, with the production of $\mathrm{H}_{2} \mathrm{~S}$ leading to corrosion [40]. Besides altering the turbidity, taste, odor, and color of the water $[39,48]$ and, thus, making it impossible to meet established water criteria, the growth of biofilms carries another concern for DWDS. The presence of biofilms attached to pipe walls may be responsible for pressure losses in the systems [49] and, subsequently, diminish the distribution ability of the system as well as increase power consumption and energy losses [50]. The work of Flemming, Percival, and Walker [39] offers a general look at the problems caused by biofilms in DW.

\subsection{Impact of ECs on Biofilms}

Most available studies either focus on the impact of ECs on various aquatic animal species or their potential effects on human health. However, it is possible to find some studies which describe the effect of ECs on the behavior of the natural microbiota found in different water sources, such as river biofilms, marine sediment biofilms, and other aquatic ecosystems, as well as in engineered systems [51].

Concerning the impact of these contaminants on the aquatic microbiome, particularly in biofilms, it is possible to highlight some studies. Proia, et al. [52] investigated the effect of various drugs and pesticides on river biofilms. Of the 57 drugs and 16 pesticides detected in water, it was found that analgesics and anti-inflammatory drugs significantly affected biofilms, specifically at structure and function levels. Another study looked into the effect of the herbicide Diuron (3-(3,4-dichlorophenyl)-1,1-dimethylurea) and the biocide triclosan on aquatic biofilms and verified that these compounds affected biofilms in terms of structure and function [53]. In a more recent study, Miao, et al. [54] investigated the effects of nanoplastics (NPs) on the metabolic function of freshwater biofilms. The results suggested that elevated concentrations of NPs caused an inhibition of the biofilm metabolic diversity and altered the utilization of certain carbon sources. Other studies, focused on the impact of antimicrobial agents, particularly triclosan, in the increased biofilm resistance [55-58].

Since the removal of ECs in WWTPs and DWTPs is not completely effective, naturally present microorganisms in DWDSs, mostly in their sessile form, are inevitably exposed to ECs. The presence of ECs may affect the behavior of microorganisms in these systems, particularly when it comes to community diversity and dissemination of antimicrobial resistance [51]. However, and despite its relevance, the number of studies on the effects of ECs in the microbiota present in DWDSs is low. To the best of our knowledge, only five studies on the subject are available [59-62]. Nevertheless, while these studies may offer 
some insight on the subject matter, it is important to highlight that these, (except $[61,62]$ ) were developed with bacteria isolated from DWDS, which does not correctly represent the microbiota found in these locations. Besides that, these studies only cover a very small portion of the ECs detected in DW. Likewise, it should be noted that river biofilms, or other types of aquatic biofilms, differ significantly from those found in DWDS, particularly regarding its constituent species and the occurrence of disinfectants (Gomes et al., 2018). So, any comparison between them is limited.

\section{Musk Fragrances in Aquatic Systems}

Musk fragrances are commonly used additives in a wide range of products available in the market, from soaps, shampoos, and perfumes, to detergents and household products [2] The presence of fragrances in these kinds of products has become a requirement for most consumers, a consequence of the association of fragrance with a pleasant user experience. In addition, the use of a fragrance influences the perception of the consumer on certain products, so their addition is often desirable by manufacturers. The global demand for musk fragrances is indeed so large that it could not be met by the naturally available sources, which forced the industry to find cheaper alternatives in the form of synthetic musks, compounds that are structurally different yet similar in odor to their natural equals [63].

Synthetic musks can be divided into four categories: macrocyclic, alicyclic, polycyclic, and nitro musks. Polycyclic musks include some of the most popular and widely used musk fragrances, tonalid (AHTN) and galaxolide (HHCB). Table 1 presents the most commonly found musk in DW, their chemical structures, and some other properties. Recently, synthetic musks have been gaining notoriety as ECs due to their potential toxicity to the environment, particularly to aquatic ecosystems [3]. The personal use of hygiene products, cosmetics, and fragrance products, as well as detergents and home care products, constitute the main route of entrance for musk fragrances in WWTPs. On one hand, direct application of hygiene and cosmetic products leads to their disposal in domestic effluents. On the other hand, the application of detergents culminates in their direct discharge in sewers and subsequent arrival at WWTPs. Although fragrances present in PCPs are purely intended for external use, multiple substances derived from them are absorbed by the human body and are eventually excreted into ecosystems [64]. In addition, and similar to several other ECs, the treatments currently applied in WWTPs do not completely remove these contaminants [59]. Consequently, musk fragrances are transported in wastewater and effluents after their use, continuing their journey to different water resources, such as groundwater and surface water, as well as water intended for human consumption, culminating in their accumulation in organisms and trophic chains (bioaccumulation and biomagnification) [2]. Rimkus [65] reviewed the presence of polycyclic musk contaminants in environmental samples, including water, sediment particulate matter, sewage, and biota emphasizing their persistence in aquatic environments. Moreover, musk compounds have been detected in wastewater effluents in proportion to the population served. The presence of musk has been also detected in air, including in the air around WWTPs [66]. Also, it presence in water bodies receiving effluents from WWTPs has been reported [67]. However, Chase, et al. [68] detected musk contaminants at $\mathrm{ng} / \mathrm{L}$ or $\mathrm{ng} / \mathrm{g}$ levels in playa lakes, which did not receive WWTPs effluents, clearly highlighting the One Water Concept. 
Table 1. Musk compounds most frequently detected in DW. Chemical structure designed in www. emolecules.com (accessed on 16 February 2022) and chemical properties according to the data base https:/ / pubchem.ncbi.nlm.nih.gov/ (accessed on 16 February 2022).

\begin{tabular}{|c|c|c|c|c|}
\hline Musk Fragrance & Chemical Structure & Chemical Formula & $\begin{array}{c}\text { Molecular Weight } \\
(\mathrm{g} / \mathrm{mol})\end{array}$ & $\begin{array}{l}\text { Log P (Octanol/Water } \\
\text { Partition Coefficient) }\end{array}$ \\
\hline Cashmeran & & $\mathrm{C}_{14} \mathrm{H}_{22} \mathrm{O}$ & 206.3 & 3.3 \\
\hline Cestolide & & $\mathrm{C}_{17} \mathrm{H}_{24} \mathrm{O}$ & 244.4 & 5 \\
\hline Galaxolide & & $\mathrm{C}_{18} \mathrm{H}_{26} \mathrm{O}$ & 258.4 & 4.8 \\
\hline Musk Ketone & & $\mathrm{C}_{14} \mathrm{H}_{18} \mathrm{~N}_{2} \mathrm{O}_{5}$ & 294.3 & 3.7 \\
\hline Musk xylene & & $\mathrm{C}_{12} \mathrm{H}_{15} \mathrm{~N}_{3} \mathrm{O}_{6}$ & 297.3 & 3.8 \\
\hline Phantolide & & $\mathrm{C}_{17} \mathrm{H}_{24} \mathrm{O}$ & 244.4 & 4.8 \\
\hline Tonalid & & $\mathrm{C}_{18} \mathrm{H}_{26} \mathrm{O}$ & 258.4 & 5.3 \\
\hline Traseolide & & $\mathrm{C}_{18} \mathrm{H}_{26} \mathrm{O}$ & 258.4 & 5.1 \\
\hline
\end{tabular}

Considering that musk fragrances are often found in aquatic ecosystems, their presence in the environment could potentially lead to negative impacts on aquatic species. Most available studies focus on the effects of synthetic musks on aquatic organisms, such as algae, fishes, crustaceans, amphibians, and larvae [69-72]. However, there is not much information regarding the impact of musk contaminants in microbial communities, particularly from aquatic biofilms. Considering the importance of the microbiota in aquatic ecosystems as well as the presence of biofilms in water destined for consumers, it becomes crucial to investigate the impact of the interaction between musk contaminants and biofilms. 


\subsection{Musks in Drinking Water}

The incomplete degradation of musks in WWTPs, and subsequent discharge of the resultant effluents into water matrices, results in the release of these contaminants into the environment [73]. On the other hand, in highly populated urban areas, treated municipal wastewater can be used to supplement raw-water supplies to preserve and reuse water, a process known as indirect potable water reuse [74]. Even though these contaminants generally occur in the environment at concentrations in the range of $\mathrm{ng} / \mathrm{L}-\mu \mathrm{g} / \mathrm{L}$, it is still essential to determine the frequency of occurrence of these contaminants, especially in DW, considering their incessant use, constant disposal, and unknown consequences for public health [75]. Figure 1 summarizes the different water sources where musk contaminants have been detected.

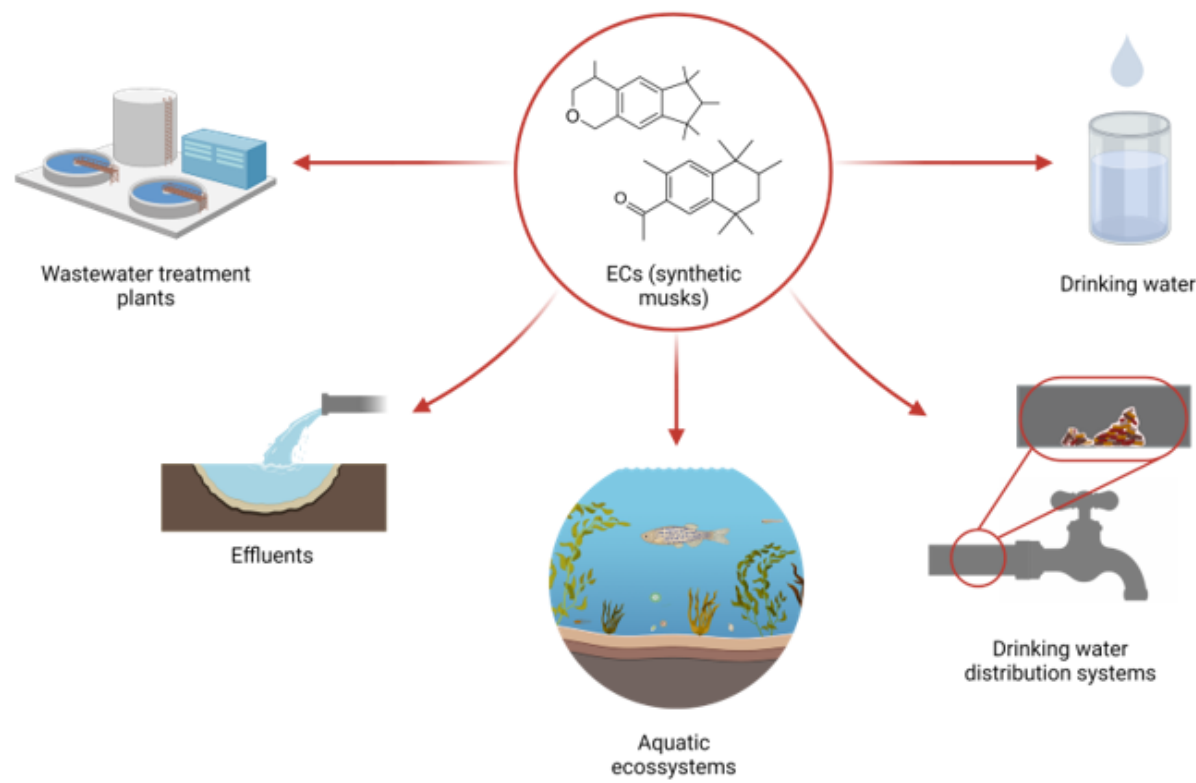

Figure 1. Main places of detection of musk contaminants in the environment.

The EU Drinking Water Directive 98/83/EC aims to protect public health from adverse effects of any contamination of water intended for human consumption (European Comission, 2020). The Directive on Environmental Quality Standards (EQSD) (Directive 2008/105/EC), also known as the Priority Substances Directive as well as the amendment made in 2013, Directive 2013/39/EU, set environmental quality standards (EQS) for substances in surface waters, listing 45 priority substances, including six priority hazardous substances [76]. However, the lack of official guidelines for musks in DW paves the way to a lack of data and published studies on the occurrence of musks in DW supplies. The exceptions are compiled in Table 2, providing the studies known to date regarding the incidence of musks in DW as well as the concentrations registered. Besides the lack of official guidelines, the very low concentration at which musks are found in DW is also a challenge that hampers their detection and quantification. Moreover, the huge variety of contaminants with different chemical structures, the products from their degradation, metabolism, or chemical interactions also demand new and more sensitive analytical and extraction strategies for multi-residue screening [77]. The results presented in Stackelberg, et al. [78] were guided by the US Geological Survey (USGS) and the Centers for Disease Control and Prevention (CDC), which collected water samples both from a DWTP and from the two streams that supply the facility, to assess the persistence of wastewater-related organic contaminants when conventional water treatments are applied. It is worth noting that the DWTP which was sampled is situated at a heavily populated and highly urbanized drainage basin and that the two streams that supply the facility are the discharge site of at least 50 WWTPs, which explains the elevated concentration values of AHTN and HHCB (two of the most widely used synthetic nitro musks) in the raw water samples. These 
compounds were detected in samples throughout the DWTP, which indicates that these are not effectively removed through the applied water treatments, including filtration with granular activated carbon (GAC) (used primarily to remove compounds that affect the odor and taste of water, and which has been reported to successfully remove other contaminants, such as bezafibrate, carbamazepine, and diclofenac) [79].

Table 2. Presence of musks in finished drinking water (effluent/reservoir in DWTPs) and in tap water (DW collected in tap) according to the search obtained from SCOPUS database (13 October 2021) using the following keywords: "Musks" AND “Drinking" AND “Water". A total of 45 works were obtained in this search, where only seven reported the quantification of musks in drinking/tap water, the remaining were obtained through the analysis of the references cited in the previously analyzed works.

\begin{tabular}{|c|c|c|c|c|c|}
\hline Origin and Year & Type of Collected Samples & Determination Method $^{\text {a }}$ & Musks $^{b}$ & $\begin{array}{c}\text { Highest } \\
\text { Concentration } \\
\text { Detected (ng/L) }\end{array}$ & Reference \\
\hline USA (2001) & Finished water & CLLE GC/MS & $\begin{array}{l}\text { AHTN } \\
\text { HHCB }\end{array}$ & $\begin{array}{l}490 \\
82 \\
\end{array}$ & [78] \\
\hline Serbia (2014) & Drinking water & $\begin{array}{c}\text { SPME and } \\
\text { GC } \times \text { GC }- \text { TOF MS }\end{array}$ & НHCB & $50 \pm 40$ & [80] \\
\hline USA (2010-2012) & Treated drinking water & $\begin{array}{l}\text { SPE and } \\
\text { GC/MS }\end{array}$ & HНCB & 61 & [81] \\
\hline USA (2001) & Treated drinking water & GC/MS & $\begin{array}{l}\text { AHTN } \\
\text { HHCB }\end{array}$ & $\begin{array}{l}0.51 \\
2.2\end{array}$ & [82] \\
\hline Ireland (2010-2011) & Finished drinking water & $\begin{array}{l}\text { LC/MS, GC/MS, } \\
\mathrm{ICP} / \mathrm{MS} \text { and IC }\end{array}$ & HНCB & 146 & [73] \\
\hline France (2004) & Finished drinking water & GC/MS & AHTN & $<1$ & [83] \\
\hline China (2018) & Tap water & SE and GC-MS/MS & $\begin{array}{c}\text { ADBI } \\
\text { AHMI } \\
\text { AHTN } \\
\text { ATII } \\
\text { HHCB }\end{array}$ & n.d. & [84] \\
\hline USA (2007) & Finished water & SPE and GC/MS & $\begin{array}{l}\text { AHTN } \\
\text { HHCB }\end{array}$ & $\begin{array}{l}36 \\
\text { n.d }\end{array}$ & [85] \\
\hline Portugal (2017) & Tap water & DLLME and GC-MS/MS & $\begin{array}{l}5 \mathrm{NM} \\
6 \mathrm{PCM} \\
2 \mathrm{MCM} \\
\end{array}$ & n.d. & [86] \\
\hline Portugal (2008-2009) & Drinking water & SPME and GC/MS & $\begin{array}{c}\text { AHTN } \\
\text { HHCB } \\
\text { MK } \\
\text { MX }\end{array}$ & n.d. & [87] \\
\hline \multicolumn{6}{|c|}{ 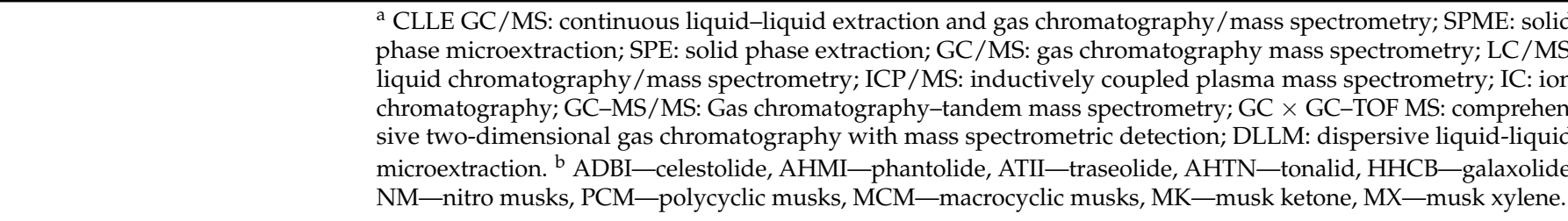 } \\
\hline
\end{tabular}

Kolpin, et al. [88] also analyzed the contribution of urban areas to the contamination of streams with organic wastewater contaminants (OWCs), becoming clear the contribution of effluent discharges to the high concentrations of musks in streams, which are then incompletely removed by traditional treatments in DWTPs. Still in the USA, a more recent study focused on assessing the presence, concentration, and survival of chemical and microbial ECs in source and treated DWs in several locations [81]. Even though HHCB was present in source water at a lower concentration than the previous studies, the presence of this contaminant in the finished DW at a concentration of $0.061 \mu \mathrm{g} / \mathrm{L}$ indicates that the treatments currently applied in WWTPs are still flawed and should be adjusted.

On the other hand, in Europe the case seems to be different. In Belgrade [80] and Paris [83], the levels of polycyclic musks in raw water, which includes river and groundwater, appears to be lower than those reported in the USA. However, the comparison between these two scenarios is limited due to diverse factors, namely the different nature of the 
samples, the different determination methods, the population of the analyzed sites as well as the quantity of WWTPs nearby and the number of effluent discharges. Nevertheless, the concentration of musks in the finished DW is lower, with both concentrations of AHTN and HHCB being below the limit of detection as reported by Pender, Read, Egan, and Waal $[73,83]$. This fact could be justified by the implementation of different and more efficient water treatments for the removal of polycyclic musks, such as the use of powdered activated carbon (PAC) in the process of clarification and ozonation [83]. In addition, two works developed in Portugal did not detect musk contaminants in DW $[86,87]$

The study of Pender, Read, Egan, and Waal [73] focused on identifying the presence of selected contaminants in DW, among which were included synthetic musks. The selected sites were two DWTPs: one located near 18 urban centers and a WWTP, and the other located near a river and downstream of another WWTP, which receives mostly agricultural and animal husbandry wastewaters. HHCB has been detected in all samples from the first DWTP and the maximum detected concentration of this contaminant in the finished DW was $0.146 \mu \mathrm{g} / \mathrm{L}$, the highest registered value out of all the studies conducted in Europe.

One of the forms to diminish the occurrence of musks in DW could consist of decreasing their concentration in source water in the first place. Considering that the main route of the entrance of musk fragrances in WWTPs is through their direct application as soaps, cosmetics, hygiene products, detergents, and home-care products, the only way to reduce musk contaminants in water sources is by implementing treatments that could be more effective on the removal of these contaminants before water reintroduction in aquatic sources. Besides ozonation, which appears to be an efficient method, visible light $\mathrm{Ce}-\mathrm{TiO}_{2}$ photocatalysis, and UV irradiation have shown promising results for the removal of synthetic musks [89]. Other advanced oxidation treatments, such as photo-Fenton and membrane filtration methods, also deserve attention and more detailed research [90]. Several studies pointed out adsorption as the main mechanism of musk removal from wastewaters, due to their lipophilic profile $[82,91]$. Sorption to activated sludge aggregates or to powered/granular activated carbon or even their adsorption to (bio)filters are examples of simple and effective strategies already implemented in conventional WWTPs to reduce the entrance of musks in water bodies [91-93]. New approaches must be applied to reduce the discharge of musks in the environment, which could be achieved through the mentioned novel methods or their combination. A reduction in the use of musks seems implausible considering their dominance in the market and societal dependence on such products, thus the development of efficient strategies for their removal remains the most viable option.

\subsection{Impact of Musk Contaminants on Microbial Communities}

Considering the high occurrence of synthetic musks in a myriad of environments, from aquatic sources, influents and effluents, to animal tissues, it is odd the almost inexistence of studies regarding the impact of musk contaminants on microbial communities. The majority of existing studies focuses on the fate of these contaminants, i.e., their occurrence in wastewater and their removal in WWTPs, rather than the effect these contaminants have on the microbial communities in these systems.

Musk compounds are typically used in personal care products to guarantee the persistence of a pleasant and lasting odor, without a specific target-organism of application. This may be one of the main reasons for the lack of information on their impact on microorganisms. Musk effects on human cells have been evaluated more extensively since there is a widespread and daily use of a variety of musk compounds in direct contact with the human body. However, the impact on microbial communities may also be disregarded due to the residual concentrations of musks detected in the environment, despite the high ability of musk to be adsorbed by the biomass, within microbial aggregates. In fact, most of the works regarding the interaction between ECs and microbial communities are focused on water treatment and musk contaminants biodegradation and sorption. Although several works have described the use of microbial communities, such as activated sludge, on the 
removal of musks from water, the impact of musks in the biomassa has not been explored. For instance, Butkovskyi, et al. [94] reported that HHCB in greywater was persistent and was only partially removed in aerobic activated sludge systems. On the other hand, Alvarino, et al. [91] tested the removal of three synthetic musk fragrances-AHTN, HHCB and celestolide (ADBI) in a UASB reactor coupled to an aerobic membrane bioreactor (MBR). The authors reported a significantly higher sorption of the musk fragrances in the MBR when compared to conventional activated sludge systems, due to smaller biomass particle sizes. At the same time, the sorption contribution of the anaerobic granules in the UASB reactor proved to be far less than the one observed for the aerobic sludge, due to differences in biomass concentration. A previous study by Alvarino, et al. [95] concluded, in a similar way, that sorption of lipophilic compounds, namely the musk fragrances previously mentioned, is heavily dependent on biomass concentration and, thus, was more significant in the UASB reactor. When it comes to nitrifying activity, Fernandez-Fontaina, et al. [96] tested the biodegradation and sorption of AHTN and HHCB in nitrifying activated sludge (NAS). The results revealed that the NAS had different affinities for each of the compounds tested and had a high affinity for the musk substances, resulting in increased biodegradation of these compounds, particularly when it comes to HHCB. The review of Sousa, et al. [97] offers an in-depth analysis of the removal of ECs, including synthetic musks, through different treatment strategies. Although most studies do not assess the impact of musk contaminants on sludge organisms and are only focused on their removal ability, there are still few examples of such effects. In the first place, the study of Wei, et al. [98] evaluated the effects of the presence of HHCB in waste activated sludge (WAS) in the process of anaerobic digestion in continuous lab-scale digesters. The results allowed to conclude that exposure of WAS to a concentration of 90-200 mg/kg-dw of HHCB, significantly inhibited volatile solid degradation causing a decrease in methane production. On the other hand, the study of Cao, et al. [99] demonstrated that the presence of AHTN in similar systems might have an opposite effect. When WAS or synthetic wastewaters were put into contact with AHTN at concentrations ranging from 0 to $1000 \mathrm{mg} / \mathrm{kg}$ TSS, the methane production increased from $125.0 \pm 2.2$ to $162.9 \pm 1.6 \mathrm{~mL} / \mathrm{g}$ VSS. Additionally, in the presence of AHTN, there was an increase in the population of methanogenic archaea, which also resulted in the acceleration of methane production.

It is widely known that microbial communities in soil and aquatic environments are essential in degradation processes and biogeochemical cycles. However, there are strikingly few studies regarding the effect of contaminants in environmental bacterial communities. There are two examples of studies on this matter $[100,101]$. The study of Lv, Hu, An, and Wei [100] aimed to assess the joint effects of cadmium and HHCB on soil microbiomes. After mixing the farmland soil with a stock solution of $\mathrm{HHCB}$ and cadmium chloride $\left(\mathrm{CdCl}_{2}\right)$, samples were collected after 4 weeks. The results obtained showed that the contamination of the soil with $\mathrm{HHCB}$ and $\mathrm{CdCl}_{2}$ stimulated the reproduction of the soil microorganisms, which increased the utilization of carbon sources, including carbohydrates, esters, alcohols, and carboxylic acids. Moreover, the effects of HHCB were also studied by Peng, Kiggen, Pan, Bracewell, Ying, Salvito, Selck, and Brink [101] in a subtropical freshwater consortium, characterized by the presence of algae, crustaceans, clams, snails, midges, benthic worms, and bacteria. While the addition of HHCB at $300 \mu \mathrm{g} / \mathrm{g}$ per dry weight of sediment had no direct effect on the sediment bacterial community (i.e., structure, richness, and diversity), the presence of HHCB at the same concentration or even lower, affected the survival of benthic macroinvertebrates, which significantly altered the bacterial community structure in the sediment.

Nevertheless, the studies regarding the effects of the presence of nitro musks are even more scarce, with only one example being found. The study of Duygan, et al. [102] aimed to quantify the growth of freshwater microbial communities and the biotransformation potential of selected contaminants, including musk xylene, through flow cytometry. These authors measured substrate utilization, $\mathrm{CO}_{2}$ evolution, and net biomass formation. The results displayed no significant net biomass formation of the freshwater com- 
munity at a concentration of $10 \mathrm{mg} \mathrm{C} / \mathrm{L}$ of musk xylene. The lack of measurable $\mathrm{CO}_{2}$ evolution and the persistence of the parent compound revealed that this contaminant is non-biodegradable [102].

The knowledge about the impact of musk contaminants in DW microbial communities is also very limited. So far, and to the best of our knowledge, only two studies focused on the impact of musks on DW bacteria. The work of Gomes, et al. [103] aimed to study the effects of different PPCPs, including AHTN and HHCB on the motility and biofilm formation capacity of Burkholderia cepacia, previously isolated from a DWDSs. The authors tested the effects of the selected contaminants in biofilm formation and control, assessing the biofilm culturability through the enumeration of colony forming units (CFUs) and evaluating the susceptibility of $24 \mathrm{~h}$ old biofilms to sodium hypochlorite $(\mathrm{NaOCl})$. The referred work also evaluated the effects of EC exposure on bacterial motility (swimming and swarming) and the bacteria susceptibility to two antibiotics, trimethoprim (TMP) and sulfamethoxazole (SMX). Overall, the selected contaminants did not produce a significant effect on cell motility, biofilm production and susceptibility to TMP-SMX. However, the exposure of bacteria to HHCB affected cell motility, specifically the bacterial swarming motility as well as the tolerance to TMP-SMX. Another study by Gomes, Simões, and Simões [59] attempted to determine the effects of long-term exposure (26 days) of Stenotrophomonas maltophilia to several ECs, including AHTN and HHCB. Both the planktonic behavior and the biofilm behavior of the bacterial cells exposed to ECs were characterized. The planktonic cells grown in the presence of ECs were tested in terms of susceptibility to $\mathrm{NaOCl}$ and selected antibiotics, levofloxacin (LEV) and TMP-SMX. The sessile cells were characterized in terms of biofilm formation and susceptibility to $\mathrm{NaOCl}$. The results revealed that long term exposure of ECs, specifically the tested musks, did not produce significant effects on planktonic and sessile S. maltophilia. Although the authors concluded that the formation of biofilms was not significantly affected by exposure to the compounds, it was found that exposure to HHCB caused a slight increase in their number of culturable cells.

\section{Conclusions}

ECs, such as synthetic musks, occur frequently in several water sources, including on DW. However, the effects of their exposure in the microbiome are still underexplored. Research on ECs is mostly focused on the impact of pharmaceutical drugs, particularly antibiotics. The continuous use of PPCPs and the constant disposal of derived metabolites did not demonstrate a sign of slowing down as modern society has grown dependent on these products. This, paired with the low removal efficiency of conventional treatments applied in WWTPs, makes it imperative to prioritize the research to effectively understand the impact of ECs in the environment. Besides, EC exposure could produce vastly different effects depending on several factors, from concentration to hydrodynamic conditions, stress factors, and combination of contaminants, among many others. A combination of collaborative research on the subject as well as the application of novel approaches on wastewater treatments could be key to overpass this challenge.

The scarce information concerning the impact of synthetic musks on microbial communities in general, and specifically in water and DW microbiota, limit the real understanding of their impact in ecosystems' equilibrium as well as the perception of the risk for public health. The present work demonstrates that some musk contaminants may produce significant effects on microbial communities; however, more data are required to determine if these effects would be significant at environmentally relevant concentrations. Additionally, the available literature is not conclusive about the effects of such contaminants on DW microbiota as the scarce number of studies with representative microbial communities makes it impossible to make general conclusions. Therefore, research is demanding on the assessment of the presence of musks in DW all over the world and their impact on microbial communities, with further consequences for public health.

Author Contributions: Conceptualization, I.B.G. and M.S.; methodology, V.A. and I.B.G.; investigation, V.A. and I.B.G.; resources, M.S.; data curation, V.A.; writing-original draft preparation, V.A.; 
writing - review and editing, I.B.G. and M.S.; supervision, I.B.G. and M.S.; project administration, M.S.; funding acquisition, M.S. All authors have read and agreed to the published version of the manuscript.

Funding: This work was financially supported by: LA/P/0045/2020 (ALiCE), UIDB/00511/2020 and UIDP/00511/2020 (LEPABE), funded by national funds through FCT/MCTES (PIDDAC); Projects Biocide_for_Biofilm-TDC/BII-BTI/30219/2017-POCI-01-0145-FEDER-030219; Germirrad-POCI01-0247-FEDER-072237 funded by FEDER funds through COMPETE2020_Programa Operacional Competitividade e Internacionalização (POCI) and by national funds (PIDDAC) through FCT/MCTES Project "HealthyWaters-Identification, Elimination, Social Awareness and Education of Water Chemical and Biological Micropollutants with Health and Environmental Implications", with reference NORTE-01-0145-FEDER-000069, supported by Norte Portugal Regional Operational Programme (NORTE 2020), under the PORTUGAL 2020 Partnership Agreement, through the European Regional Development Fund (ERDF).

Institutional Review Board Statement: Not applicable.

Informed Consent Statement: Not applicable.

Data Availability Statement: Not applicable.

Conflicts of Interest: The authors declare no conflict of interest.

\section{References}

1. Rosenfeld, P.E.; Feng, L.G.H. Emerging Contaminants; Elsevier Inc.: Amsterdam, The Netherlands, 2011 ; pp. $215-222$.

2. Smital, T. Acute and chronic effects of emerging contaminants. In Emerging Contaminants from Industrial and Municipal Waste. The Handbook of Environmental Chemistry; Barceló, D., Petrovic, M., Eds.; Springer: Berlin/Heidelberg, Germany, 2008; Volume 5, pp. 105-142. [CrossRef]

3. Yan, S.; Subramanian, S.B.; Tyagi, R.D.; Surampalli, R.Y.; Zhang, T.C. Emerging contaminants of environmental concern: Source, transport, fate, and treatment. J. Hazard. Toxic Radioact. Waste 2010, 14, 2-20. [CrossRef]

4. Rahman, M.F.; Yanful, E.K.; Jasim, S.Y. Endocrine disrupting compounds (EDCs) and pharmaceuticals and personal care products (PPCPs) in the aquatic environment: Implications for the drinking water industry and global environmental health. J. Water Health 2009, 7, 224-243. [CrossRef] [PubMed]

5. Ternes, T.A.; Stumpf, M.; Mueller, J.; Haberer, K.; Wilken, R.D.; Servos, M. Behavior and occurrence of estrogens in municipal sewage treatment plants-I. Investigations in Germany, Canada and Brazil. Sci. Total Environ. 1999, 225, 81-90. [CrossRef]

6. Jurado, A.; Vazquez-Sune, E.; Carrera, J.; Lopez de Alda, M.; Pujades, E.; Barcelo, D. Emerging organic contaminants in groundwater in Spain: A review of sources, recent occurrence and fate in a European context. Sci. Total Environ. 2012, 440, 82-94. [CrossRef]

7. Cui, S.; Hough, R.; Yates, K.; Osprey, M.; Kerr, C.; Cooper, P.; Coull, M.; Zhang, Z. Effects of season and sediment-water exchange processes on the partitioning of pesticides in the catchment environment: Implications for pesticides monitoring. Sci. Total Environ. 2020, 698, 134228. [CrossRef]

8. Fei, Y.; Huang, S.; Zhang, H.; Tong, Y.; Wen, D.; Xia, X.; Wang, H.; Luo, Y.; Barcelo, D. Response of soil enzyme activities and bacterial communities to the accumulation of microplastics in an acid cropped soil. Sci. Total Environ. 2020, 707, 135634. [CrossRef]

9. Burgos-Aceves, M.A.; Abo-Al-Ela, H.G.; Faggio, C. Impact of phthalates and bisphenols plasticizers on haemocyte immune function of aquatic invertebrates: A review on physiological, biochemical, and genomic aspects. J. Hazard Mater. 2021, 419, 126426. [CrossRef]

10. Burgos-Aceves, M.A.; Migliaccio, V.; Di Gregorio, I.; Paolella, G.; Lepretti, M.; Faggio, C.; Lionetti, L. 1,1,1-trichloro-2,2-bis (p-chlorophenyl)-ethane (DDT) and 1,1-Dichloro-2,2-bis (p, p'-chlorophenyl) ethylene (DDE) as endocrine disruptors in human and wildlife: A possible implication of mitochondria. Environ. Toxicol. Pharm. 2021, 87, 103684. [CrossRef]

11. Koagouw, W.; Arifin, Z.; Olivier, G.W.J.; Ciocan, C. High concentrations of paracetamol in effluent dominated waters of Jakarta Bay, Indonesia. Mar. Pollut. Bull. 2021, 169, 112558. [CrossRef]

12. Melo, L.E.; de Paulo, D.V.; Montagner, C.C.; Carvalho, P.S.M. Behavioral and reproductive effects in Poecilia vivipara males from a tropical estuary affected by estrogenic contaminants. Mar. Pollut. Bull. 2021, 169, 112543. [CrossRef]

13. Brodin, T.; Piovano, S.; Fick, J.; Klaminder, J.; Heynen, M.; Jonsson, M. Ecological effects of pharmaceuticals in aquatic systems-impacts through behavioural alterations. Philos. Trans. R. Soc. B Biol. Sci. 2014, 369, 20130580. [CrossRef]

14. Simon, M.; Grossart, H.-p.; Schweitzer, B.; Ploug, H. Microbial ecology of organic aggregates in aquatic ecosystems. Aquat. Microb. Ecol. 2002, 28, 175-211. [CrossRef]

15. Geng, N.; Wu, Y.; Zhang, M.; Tsang, D.C.W.; Rinklebe, J.; Xia, Y.; Lu, D.; Zhu, L.; Palansooriya, K.N.; Kim, K.H.; et al. Bioaccumulation of potentially toxic elements by submerged plants and biofilms: A critical review. Environ. Int. 2019, 131, 105015. [CrossRef] [PubMed]

16. Hu, X.; Kang, F.; Yang, B.; Zhang, W.; Qin, C.; Gao, Y. Extracellular polymeric substances acting as a permeable barrier hinder the lateral transfer of antibiotic resistance genes. Front. Microbiol. 2019, 10, 736. [CrossRef] [PubMed] 
17. Wimpenny, J.; Manz, W.; Szewzyk, U. Heterogeneity in biofilms. FEMS Microbiol. Rev. 2000, 24, 661-671. [CrossRef] [PubMed]

18. Juanita, M.-G.; Freixa, A.; Perujo, N.; Barral-Fraga, L. Limits of the Biofilm Concept and Types of Aquatic Biofilms, 1st ed.; Romaní, A.M., Guasch, H., Balaguer, M.D., Eds.; Caister Academic Press: Norfolk, UK, 2016; pp. 3-27.

19. Katharina, B. Microbial Biodiversity in Natural Biofilms, 1st ed.; Romaní, A.M., Guasch, H., Balaguer, M.D., Eds.; Caister Academic Press: Norfolk, UK, 2016; pp. 63-87.

20. Larned, S.T. A prospectus for periphyton: Recent and future ecological research. J. N. Am. Benthol. Soc. 2010, $29,182-206$. [CrossRef]

21. Jesus, B.; Brotas, V.; Ribeiro, L.; Mendes, C.R.; Cartaxana, P.; Paterson, D.M. Adaptations of microphytobenthos assemblages to sediment type and tidal position. Cont. Shelf. Res. 2009, 29, 1624-1634. [CrossRef]

22. Pan, J.; Bournod, C.N.; Cuadrado, D.G.; Vitale, A.; Piccolo, M.C. Interaction between Estuarine Microphytobenthos and Physical Forcings: The Role of Atmospheric and Sedimentary Factors. Int. J. Geosci. 2013, 04, 352-361. [CrossRef]

23. Dupraz, C.; Visscher, P.T. Microbial lithification in marine stromatolites and hypersaline mats. Trends Microbiol. 2005, 13, 429-438. [CrossRef]

24. Pusch, M.; Fiebig, D.; Brettar, I.; Eisenmann, H.; Ellis, B.K.; Lake, F.; Station, B.; Kaplan, L.A.; Water, S.; Lock, M.A.; et al. The role of micro-organisms in the ecological connectivity of running waters. Freshw. Biol. 1998, 40, 453-495. [CrossRef]

25. Sabater, S.; Guasch, H.; Roman, A.; Muñoz, I. The effect of biological factors on the efficiency of river biofilms in improving water quality. Hydrobiologia 2002, 469, 149-156. [CrossRef]

26. Underwood, G.J.C.; Perkins, R.G.; Consalvey, M.C.; Hanlon, A.R.M.; Oxborough, K.; Baker, N.R.; Paterson, D.M. Patterns in microphytobenthic primary productivity: Species-specific variation in migratory rhythms and photosynthetic efficiency in mixed-species biofilms. Limnol. Oceanogr. 2005, 50, 755-767. [CrossRef]

27. Anderson-Glenna, M.J.; Bakkestuen, V.; Clipson, N.J.W. Spatial and temporal variability in epilithic biofilm bacterial communities along an upland river gradient. FEMS Microbiol. Ecol. 2008, 64, 407-418. [CrossRef] [PubMed]

28. Romaní, A.M.; Sabater, S. Structure and activity of rock and sand biofilms in a Mediterranean stream. Ecology 2001, 82, 3232-3245. [CrossRef]

29. Sabater, S.; Guasch, H.; Ricart, M.; Romaní, A.; Vidal, G.; Christina, K.; Schmitt-Jansen, M. Monitoring the effect of chemicals on biological communities. The biofilm as an interface. Anal. Bioanal. Chem. 2007, 387, 1425-1434. [CrossRef]

30. Berry, D.; Xi, C.; Raskin, L. Microbial ecology of drinking water distribution systems. Curr. Opin. Biotechnol. 2006, 17, $297-302$. [CrossRef]

31. López, D.; Vlamakis, H.; Kolter, R. Biofilms. Cold Spring Harb. Perspect Biol. 2010, 2, 1-12. [CrossRef]

32. Mah, T.F.C.; O'Toole, G.A. Mechanisms of biofilm resistance to antimicrobial agents. Trends Microbiol. 2001, 9, 34-39. [CrossRef]

33. MacLeod, F.A.; Guiot, S.R.; Costerton, J.W. Layered structure of bacterial aggregates produced in an upflow anaerobic sludge bed and filter reactor. Appl. Environ. Microbiol. 1990, 56, 1598-1607. [CrossRef]

34. Ryhiner, G.K.S.B.B.; Gros, H. Biofilm reactors configuration for advanced nutrient removal. Water Sci. Technol. 1994, 29 , 111-117. [CrossRef]

35. Fernandes, S.; Gomes, I.B.; Simões, L.C.; Simões, M. Overview on the hydrodynamic conditions found in industrial systems and its impact in (bio)fouling formation. Chem. Eng. J. 2021, 418, 129348. [CrossRef]

36. Christie, A.O.; Dalley, R. Barnacle Fouling and Its Prevention, 1st ed.; Southward, A.J., Ed.; CRC/Balkema: Rotterdam, The Netherlands, 1987; pp. 419-433.

37. Schultz, M.P.; Bendick, J.A.; Holm, E.R.; Hertel, W.M. Economic impact of biofouling on a naval surface ship. Biofouling 2011, 27, 87-98. [CrossRef] [PubMed]

38. Sadekuzzaman, M.; Yang, S.; Mizan, M.F.R.; Ha, S.D. Current and Recent Advanced Strategies for Combating Biofilms. Compr. Rev. Food Sci. Food Saf. 2015, 14, 491-509. [CrossRef]

39. Flemming, H.C.; Percival, S.L.; Walker, J.T. Contamination potential of biofilms in water distribution systems. Water Sci. Tecnol. 2002, 2, 271-280. [CrossRef]

40. Percival, S.L.; Walker, J.T.; Hunter, P.R. Biofilm Formation in Potable Water, 1st ed.; Vreeland, R.H., Ed.; CRC Press: Boca Raton, FL, USA, 2000; pp. 85-102.

41. Donlan, M.R. Biofilms: Microbial Life on Surfaces. Emerg. Infect. Dis. 2002, 8, 881-890. [CrossRef] [PubMed]

42. Camper, A.; Burr, M.; Ellis, B.; Butterfield, P.; Abernathy, C. Development and structure of drinking water biofilms and techniques for their study. J. App. Microbiol. Symp. Supp. 1999, 85, 1S-12S. [CrossRef] [PubMed]

43. Fish, K.; Osborn, A.M.; Boxall, J.B. Biofilm structures (EPS and bacterial communities) in drinking water distribution systems are conditioned by hydraulics and influence discolouration. Sci. Total Environ. 2017, 593-594, 571-580. [CrossRef]

44. Gomes, I.B.; Simões, M.; Simões, L.C. The effects of sodium hypochlorite against selected drinking water-isolated bacteria in planktonic and sessile states. Sci. Total Environ. 2016, 565, 40-48. [CrossRef]

45. Simões, L.C.; Simões, M. Biofilms in drinking water: Problems and solutions. RSC Adv. 2013, 3, 2520-2533. [CrossRef]

46. Liu, G.; Zhang, Y.; Mark, E.V.D.; Knezev, A.; Pinto, A.; Bogert, B.V.D.; Liu, W.; Meer, W.V.D.; Medema, G. Assessing the origin of bacteria in tap water and distribution system in an unchlorinated drinking water system by SourceTracker using microbial community fingerprints. Water Res. 2018, 138, 86-96. [CrossRef]

47. Percival, S.L.; Walker, J.T.; Hunter, P.R. Disinfection and Control of Biofilms in Potable Water, 1st ed.; Vreeland, R.H., Ed.; CRC Press: Boca Raton, FL, USA, 2000; pp. 199-220. 
48. Simões, L.C. Biofilms in Drinking Water: Formation and Control; LAP LAMBERT Academic Publishing: Saarbrücken, Germany, 2012.

49. Bryers, J.; Characklis, W. Early fouling biofilm formation in a turbulent flow system: Overall kinetics. Water Res. 1981, $15,483-491$. [CrossRef]

50. Trulear, M.G.; Characklis, W.G. Dynamics of biofilm processes. Water Pollut. Control Fed. 1982, 54, 1288-1301. [CrossRef]

51. Gomes, I.B.; Maillard, J.-Y.; Simões, L.C.; Simões, M. Emerging contaminants affect the microbiome of water systems-Strategies for their mitigation. NPJ Clean Water 2020, 3, 39. [CrossRef]

52. Proia, L.; Osorio, V.; Soley, S.; Köck-Schulmeyer, M.; Pérez, S.; Barceló, D.; Romaní, A.M.; Sabater, S. Effects of pesticides and pharmaceuticals on biofilms in a highly impacted river. Environ. Pollut. 2013, 178, 220-228. [CrossRef] [PubMed]

53. Proia, L.; Morin, S.; Peipoch, M.; Romaní, A.M.; Sabater, S. Resistance and recovery of river biofilms receiving short pulses of Triclosan and Diuron. Sci. Total Environ. 2011, 409, 3129-3137. [CrossRef]

54. Miao, L.; Guo, S.; Liu, Z.; Liu, S.; You, G.; Qu, H.; Hou, J. Effects of Nanoplastics on Freshwater Biofilm Microbial Metabolic Functions as Determined by BIOLOG ECO Microplates. Int. J. Environ. Res. Public Health 2019, 16, 4639. [CrossRef]

55. Drury, B.; Scott, J.; Rosi-Marshall, E.J.; Kelly, J.J. Triclosan exposure increases triclosan resistance and influences taxonomic composition of benthic bacterial communities. Environ. Sci. Technol. 2013, 47, 8923-8930. [CrossRef]

56. Carey, D.E.; McNamara, P.J. The impact of triclosan on the spread of antibiotic resistance in the environment. Front. Microbiol. 2015, 5, 780. [CrossRef]

57. Carey, D.E.; Zitomer, D.H.; Kappell, A.D.; Choi, M.J.; Hristovab, K.R.; McNamara, P.J. Chronic exposure to triclosan sustains microbial community shifts and alters antibiotic resistance gene levels in anaerobic digesters. Environ. Sci. Process Impacts $\mathbf{2 0 1 6}$ 18, 1060-1067. [CrossRef]

58. Fujimoto, M.; Carey, D.E.; McNamara, P.J. Metagenomics reveal triclosan-induced changes in the antibiotic resistome of anaerobic digesters. Environ. Pollut. 2018, 241, 1182-1190. [CrossRef]

59. Gomes, I.B.; Simões, L.C.; Simões, M. The effects of emerging environmental contaminants on Stenotrophomonas maltophilia isolated from drinking water in planktonic and sessile states. Sci. Total Environ. 2018, 643, 1348-1356. [CrossRef] [PubMed]

60. Gomes, I.B.; Querido, M.M.; Teixeira, J.P.; Pereira, C.C.; Simões, L.C.; Simões, M. Prolonged exposure of Stenotrophomonas maltophilia biofilms to trace levels of clofibric acid alters antimicrobial tolerance and virulence. Chemosphere 2019, 235, 327-335. [CrossRef] [PubMed]

61. Wang, H.; Hu, C.; Shen, Y.; Shi, B.; Zhao, D.; Xing, X. Response of microorganisms in biofilm to sulfadiazine and ciprofloxacin in drinking water distribution systems. Chemosphere 2019, 218, 197-204. [CrossRef] [PubMed]

62. Huo, L.; Zhao, S.; Shi, B.; Wang, H.; He, S. Bacterial community change and antibiotic resistance promotion after exposure to sulfadiazine and the role of UV/H2O2-GAC treatment. Chemosphere 2021, 283, 131214. [CrossRef]

63. Liebl, B.; Mayer, R.; Ommer, S.; Koletzko, B. Transition of nitro musks and polycyclic musks into human milk. Adv. Exp. Med. Biol. 2000, 478, 289-305. [PubMed]

64. Reddy, H.K.D. Water Pollution Control Technologies. In Encyclopedia of Sustainable Technologies; Abraham, M.A., Ed.; Elsevier: Oxford, UK, 2017; pp. 3-22.

65. Rimkus, G.G. Polycyclic musk fragrances in the aquatic environment. Toxicol. Lett. 1999, 111, 37-56. [CrossRef]

66. Wong, F.; Robson, M.; Melymuk, L.; Shunthirasingham, C.; Alexandrou, N.; Shoeib, M.; Luk, E.; Helm, P.; Diamond, M.L.; Hung, H. Urban sources of synthetic musk compounds to the environment. Environ. Sci. Process Impacts 2019, $21,74-88$. [CrossRef]

67. Hong, J.-H.; Lee, J.-Y.; Ha, H.-J.; Lee, J.-H.; Oh, S.-R.; Lee, Y.-M.; Lee, M.-Y.; Zoh, K.-D. Occurrence and Sources of Synthetic Musk Fragrances in the Sewage Treatment Plants and the Han River, Korea. Water 2021, 13, 392. [CrossRef]

68. Chase, D.A.; Karnjanapiboonwong, A.; Fang, Y.; Cobb, G.P.; Morse, A.N.; Anderson, T.A. Occurrence of synthetic musk fragrances in effluent and non-effluent impacted environments. Sci. Total Environ. 2012, 416, 253-260. [CrossRef]

69. Schramm, K.W.; Kaune, A.; Beck, B.; Thumm, W.; Behechti, A.; Kettrup, A.; Nickolova, P. Acute toxicities of five nitromusk compounds in Daphnia, algae and photoluminescent bacteria. Water Res. 1996, 30, 2247-2250. [CrossRef]

70. Balk, F.; Ford, R.A. Environmental risk assessment for the polycyclic musks, AHTN and HHCB: II. Effect assessment and risk characterisation. Toxicol. Lett. 1999, 111, 81-94. [CrossRef]

71. Giddings, J.M.; Salvito, D.; Putt, A.E. Acute toxicity of 4-amino musk xylene to Daphnia magna in laboratory water and natural water. Water Res. 2000, 34, 3686-3689. [CrossRef]

72. Artola-Garicano, E.; Sinnige, T.L.; Holsteijn, I.v.; Vaes, W.H.J.; Hermens, J.L.M. Bioconcentration and acute toxicity of polycyclic musks in two benthic organisms (Chironomus riparius and Lumbriculus variegatus). Environ. Toxicol. Chem. 2003, 22, 1086-1092. [CrossRef] [PubMed]

73. Pender, J.; Read, C.; Egan, J.; Waal, T.D. Evaluation of emerging waterborne contaminants in Ireland. Water Sci. Tecnol. 2015, 15, 1228-1235. [CrossRef]

74. Rodriguez, C.; Van Buynder, P.; Lugg, R.; Blair, P.; Devine, B.; Cook, A.; Weinstein, P. Indirect Potable Reuse: A Sustainable Water Supply Alternative. Int. J. Environ. Res. Public Health 2009, 6, 1174-1209. [CrossRef]

75. Talib, A.; Randhir, T.O. Managing emerging contaminants in watersheds: Need for comprehensive, systems-based strategies. Sustain. Water Qual. Ecol. 2017, 9-10,1-8. [CrossRef]

76. 98/83/EC, W.S.a.T. Council Directive 98/83/EC of 3 November 1998 on the Quality of Water Intended for Human Consumption. Available online: https:/ / ec.europa.eu/environment/water/water-dangersub/pri_substances.htm (accessed on 6 October 2021). 
77. Tröger, R.; Klöckner, P.; Ahrens, L.; Wiberg, K. Micropollutants in drinking water from source to tap-Method development and application of a multiresidue screening method. Sci. Total Environ. 2018, 627, 1404-1432. [CrossRef]

78. Stackelberg, P.E.; Furlong, E.T.; Meyer, M.T.; Zaugg, S.D.; Henderson, A.K.; Reissman, D.B. Persistence of pharmaceutical compounds and other organic wastewater contaminants in a conventional drinking-water- treatment plant. Sci. Total Environ. 2004, 329, 99-113. [CrossRef]

79. Ternes, T.A.; Meisenheimer, M.M.D.; Sacher, F.; Brauch, H.-J.; Haist-Gulde, B.; Preuss, G.; Wilme, U.; Zulei-Seibert, N. Removal of Pharmaceuticals during Drinking Water Treatment. Environ. Sci. Technol. 2002, 36, 3855-3863. [CrossRef]

80. Relić, D.; Popović, A.; Đorđević, D.; Čáslavský, J. Occurrence of synthetic musk compounds in surface, underground, waste and processed water samples in Belgrade, Serbia. Environ. Earth Sci. 2017, 76, 122. [CrossRef]

81. Glassmeyer, S.T.; Furlong, E.T.; Kolpin, D.W.; Batt, A.L.; Boone, J.S.; Conerly, O.; Donohue, M.J.; King, D.N.; Kostich, S.; Mash, H.E.; et al. Nationwide reconnaissance of contaminants of emerging concern in source and treated drinking waters of the United States. Sci. Total Environ. 2017, 581-582, 909-922. [CrossRef] [PubMed]

82. Wombacher, W.D.; Hornbuckle, K.C. Synthetic Musk Fragrances in a Conventional Drinking Water Treatment Plant with Lime Softening. J. Environ. Eng. 2009, 135, 1192. [CrossRef]

83. Bruchet, A.; Hochereau, C.; Picard, C.; Decottignies, V.; Rodrigues, J.M.; Janex-Habibi, M.L. Analysis of drugs and personal care products in French source and drinking waters: The analytical challenge and examples of application. Wat. Sci. Technol. 2005, 52, 53-61. [CrossRef]

84. Li, C.; Chen, J.; Chen, Y.; Wang, J.; Ping, H.; Lu, A. Graphene-Derivatized Silica Composite as Solid-Phase Extraction Sorbent Combined with GC-MS/MS for the Determination of Polycyclic Musks in Aqueous Samples. Molecules 2018, 23, 318. [CrossRef] [PubMed]

85. Stackelberg, P.E.; Gibs, J.; Furlong, E.T.; Meyer, M.T.; Zaugg, S.D.; Lippincott, R.L. Efficiency of conventional drinking-watertreatment processes in removal of pharmaceuticals and other organic compounds. Sci. Total Environ. 2007, 377, 255-272. [CrossRef] [PubMed]

86. Ramos, S.; Homem, V.; Santos, L. Simultaneous determination of synthetic musks and UV-filters in water matrices by dispersive liquid-liquid microextraction followed by gas chromatography tandem mass-spectrometry. J. Chromatogr. A 2019, 1590, 47-57. [CrossRef]

87. Machado, S.; Gonçalves, C.; Cunha, E.; Guimarães, A.; Alpendurada, M.F. New developments in the analysis of fragrances and earthy-musty compounds in water by solid-phase microextraction (metal alloy fibre) coupled with gas chromatography-(tandem) mass spectrometry. Talanta 2011, 84, 1133-1140. [CrossRef]

88. Kolpin, D.W.; Skopec, M.; Meyer, M.T.; Furlong, E.T.; Zaugg, S.D. Urban contribution of pharmaceuticals and other organic wastewater contaminants to streams during differing flow conditions. Sci. Total Environ. 2004, 328, 119-130. [CrossRef]

89. Santiago-Morales, J.; Gómez, M.J.; Herrera-López, S.; Fernández-Alba, A.R.; García-Calvo, E.; Rosal, R. Energy efficiency for the removal of non-polar pollutants during ultraviolet irradiation, visible light photocatalysis and ozonation of a wastewater effluent. Water Res. 2013, 47, 5546-5556. [CrossRef]

90. Homem, V.; Silva, J.A.; Ratola, N.; Santos, L.; Alves, A. Long lasting perfume-A review of synthetic musks in WWTPs. J. Environ. Manag. 2015, 149, 168-192. [CrossRef]

91. Alvarino, T.; Suárez, S.; Garrido, M.; Lema, J.M.; Omil, F. A UASB reactor coupled to a hybrid aerobic MBR as innovative plant configuration to enhance the removal of organic micropollutants. Chemosphere 2016, 144, 452-458. [CrossRef] [PubMed]

92. Tasselli, S.; Valenti, E.; Guzzella, L. Polycyclic musk fragrance (PMF) removal, adsorption and biodegradation in a conventional activated sludge wastewater treatment plant in Northern Italy. Environ. Sci. Pollut. Res. 2021, 28, 38054-38064. [CrossRef] [PubMed]

93. Artola-Garicano, E.; Borkent, I.; Hermens, J.L.M.; Vaes, W.H.J. Removal of Two Polycyclic Musks in Sewage Treatment Plants: Freely Dissolved and Total Concentrations. Environ. Sci. Technol. 2003, 37, 3111-3116. [CrossRef] [PubMed]

94. Butkovskyi, A.; Rijnaarts, H.H.M.; Zeeman, G.; Leal, L.H. Fate of Personal Care and Household Products in Source Separated Sanitation. J. Hazard. Mater. 2016, 320, 427-434. [CrossRef] [PubMed]

95. Alvarino, T.; Suarez, S.; Lema, J.M.; Omil, F. Understanding the removal mechanisms of PPCPs and the influence of main technological parameters in anaerobic UASB and aerobic CAS reactors. J. Hazard Mater. 2014, 278, 506-513. [CrossRef]

96. Fernandez-Fontaina, E.; Omil, F.; Lema, J.M.; Carballa, M. Influence of nitrifying conditions on the biodegradation and sorption of emerging micropollutants. Water Res. 2012, 46, 5434-5444. [CrossRef]

97. Sousa, H.; Sousa, C.A.; Simões, L.C.; Simões, M. Microalgal-based removal of contaminants of emerging concern. J. Hazard. Mater. 2022, 423, 127153. [CrossRef]

98. Wei, W.; Wu, L.; Liu, X.; Chen, Z.; Hao, Q.; Wang, D.; Liu, Y.; Peng, L.; Ni, B.-j. How does synthetic musks affect methane production from the anaerobic digestion of waste activated sludge? How does synthetic musks affect methane production from the anaerobic digestion of waste activated sludge? Sci. Total Envioron. 2020, 713, 136594. [CrossRef]

99. Cao, Z.; Huang, X.; Wu, Y.; Wang, D.; Du, W.; Zhang, J.; Yang, Q.; Kuang, Z.; Chen, Z.; Li, X. Tonalide facilitates methane production from anaerobic digestion of waste activated sludge. Sci. Total Environ. 2021, 779, 146195. [CrossRef]

100. Lv, Z.; Hu, X.; An, J.; Wei, W. Joint effects of galaxolide and cadmium on soil microbial community function. Biomed. Res. 2017, 546-551. 
101. Peng, F.-j.; Kiggen, F.; Pan, C.-g.; Bracewell, S.A.; Ying, G.-g.; Salvito, D.; Selck, H.; Brink, P.J.V.D. Fate and effects of sedimentassociated polycyclic musk HHCB in subtropical freshwater microcosms. Ecotoxicol. Environ. Saf. 2019, 169, 902-910. [CrossRef] [PubMed]

102. Duygan, B.D.Ö.; Rey, S.; Leocata, S.; Baroux, L.; Seyfried, M. Assessing Biodegradability of Chemical Compounds from Microbial Community Growth Using Flow Cytometry. mSystems 2021, 6, e01143-20. [CrossRef]

103. Gomes, I.B.; Madureira, D.; Simões, L.C.; Simões, M. The effects of pharmaceutical and personal care products on the behavior of Burkholderia cepacia isolated from drinking water. Int. Biodeterior. Biodegrad. 2019, 141, 87-93. [CrossRef] 